Original article

\title{
Relationships between the dynamics of the durum wheat water content and its phasic development in a Mediterranean climate, for remote sensing purposes
}

\author{
Habiba CHAUKI, Nadine BRISSON, Laurent PREVOT* \\ INRA, Unité Climat, Sol \& Environnement, Domaine St-Paul, Site Agroparc, 84914 Avignon Cedex 9, France
}

(Received 11 September 2001; accepted 15 January 2003)

\begin{abstract}
The temporal evolution of the water content of durum wheat (Triticum durum L.) canopies was investigated. The water contents of leaves, stems and ears of durum wheat plants were measured on various cultivars, under various hydric treatments and for several years in the Southeast of France. Because of the variability observed between these classes of organs, the water content is expressed as the percentage of the fresh weight for each class, from which the total water content of the canopy is deduced. The water content of the organs is then modelled as a function of a decimal phenological scale, defined as the cumulative degree-days canopy temperature accumulated between key phenological stages. The phenological stage emerges as the main variable governing the time course of the relative water content. The simulated values are in good agreement with the measurements and the uncertainties of the model are comparable with experimental ones.
\end{abstract}

wheat / water content / phenological scale / desiccation / modelling

Résumé - Mise en relation de l'évolution du contenu en eau du blé dur avec son développement phénologique en climat méditerranéen, pour application à la télédétection. On étudie l'évolution temporelle du contenu en eau de couverts de blé dur (Triticum durum L.). Les contenus en eau des organes (feuilles, tiges et épis) ont été mesurés au cours de plusieurs expérimentations comprenant plusieurs variétés, plusieurs traitements hydriques et plusieurs années, dans le sud-est de la France. Du fait de la grande variabilité observée entre ces organes, on exprime le contenu en eau du blé en termes de fraction de leur poids frais, dont on peut déduire le contenu en eau total de la végétation. On modélise l'évolution du contenu en eau des organes en fonction d'une échelle phénologique relative, définie par les sommes de degrés-jours de température du couvert, accumulées entre des stades clefs du développement du blé. Dans ces conditions expérimentales, l'échelle phénologique relative explique l'essentiel de l'évolution du contenu en eau des couverts de blé. Les valeurs simulées sont en bon accord avec les mesures et les incertitudes du modèle sont du même ordre de grandeur que les erreurs expérimentales.

blé / contenu en eau / échelle phénologique / dessèchement / modélisation

\section{INTRODUCTION}

Water is the most important element in plant composition. All living tissues contain some water and the most active tissues such as leaves, growing roots and stems rarely contain less than $50 \%$ of water. Water is essential in terms of plant functioning through turgor maintainence, assimilate translocation, nutrient transport, transpiration, etc. Monitoring the plant water status was probably the first plant physiological work ever attempted [18]. Plant water status can be evaluated from visual symptoms such as wilting and leaf rolling, or measured in terms of water content or water potential [4, 26, 29]. Plant water content, $W C$, is usually expressed as relative to the plant dry weight:

$$
W C=(P F-P S) / P S
$$

or to the plant fresh weight:

$$
W C=(P F-P S) / P F
$$

where $P F$ is the fresh weight of a sample and $P S$ its dry weight (both expressed in mass units). 
Several authors have measured the daily fluctuations of water content of plants. The lowest values are usually observed in the early afternoon of clear, hot days [12]. These diurnal fluctuations are partly due to daily changes in the fresh and dry weight of the samples [3, 9, 12, 26, 29]. However, if the water content is expressed as a fraction of the fresh weight, these variations are slight [19], which justifies that in many contexts equation (2) is preferred. Despite the simplicity of its measurement, water content has been used little as a water status criterion by plant physiologists, who usually prefer to express it as relative water content [17] or water potential [11]. The main reason is that water content, $W C$, is difficult to relate to the main crop processes such as photosynthesis or leaf growth. Moreover, it is not clear whether it is a short- or a long-term characteristic of the crop.

Nevertheless, the plant water content, $W C$, has to be accounted for when interpreting remote sensing observations, since plant water content is one of the main factors affecting the signal backscattered by a canopy in the microwave domain $[1,16,30]$, but it also affects the reflectance of canopies in the solar domain, particularly in the short-wave middle infrared $[2,27]$. Knowledge of the dynamics of the canopy water content is therefore essential for modelling the microwave emission and scattering by a canopy, for estimating the surface soil moisture of vegetation-covered soils from microwave remotely-sensed data or for assimilating microwave data within crop models, whereas the water content of plants is usually not simulated by crop models.

From an experimental point of view, plant water content is often measured by destructive sampling, since only a few indirect methods allow estimation of the canopy water content throughout the growing season. Most studies have focused on ear water content and have been aimed at deriving the final yield. Bauer et al. [5] estimated the water content of wheat ears and the physiological maturity from degree-days accumulated after anthesis. Boissard et al. [7] related the water content of ears to the canopy reflectance, expressed as the normalised difference vegetation index, NDVI.

From a physiological point of view, the factors determining the components of variation of the water content of crops (or its counterpart, dry matter content) are numerous: addition of new dry matter, variation of the amount of water (not only relative water content) due to additional new tissues or organs, and processes and factors determining desiccation, especially important during the last stages. In this work desiccation is considered macroscopically as a net process resulting from loss of water and dry matter accumulations or losses (the case for stems and leaves).

The present paper relies on experimental results on durum wheat (Triticum durum L.) water content (WC) obtained at the organ level dynamically throughout the growing season for various case studies of genotypes, sowing dates and water stress. The main objective is to analyse the relationships between the crop phasic development and its water content dynamics, in view of predicting the crop water content over the crop cycle. This should improve the usefulness of microwave remotely-sensed data, by allowing the coupling of radar data with crop models or accounting for the effect of the vegetation when estimating the surface moisture of soils.

\section{MATERIALS AND METHODS}

\subsection{Experimental context}

The wheat water content dataset used in this paper originates from several field experiments conducted at the INRA Research Centre in Avignon, France (4354 N, $4^{\circ} 48 \mathrm{E}$ ) during the years 1992, 1994, 1996 and 1998. Wheat (Triticum durum L.) cv. arcour (1992), cv. ambral (1994 and 1996) and cv. armet (1998) were sown, respectively, on 18 February, 16 November, 21 November and 28 October. The use of these data allowed a large variability in terms of sowing dates and genotypes. The soil is a calcareous fluvisol with $30 \%$ clay and $100 \mathrm{~mm}$ of available water. The climate is of Mediterranean type with an average annual rainfall of $700 \mathrm{~mm}$.

In 1992, 1994 and 1996, the field was divided into two sections. One section was irrigated by sprinklers (1992) or by oscillating spray lines (1994 and 1996). The irrigation was managed so as to maintain the pre-dawn leaf potential between -0.2 and $-0.5 \mathrm{MPa}$. A PVC shelter (180- $\mu \mathrm{m}$ thickness) covered the other section, excluding all irrigation and rain. The shelter was installed at early stages (sowing or beginning of tillering). In 1998, the field was rain-fed. Two additional irrigations were applied when the soil water deficit was estimated to be close to $100 \mathrm{~mm}$. In all four experiments, the amount of nitrogen fertiliser was non-limiting; diseases were also controlled.

\subsection{Experimental measurements}

\subsubsection{Biological measurements}

The plant was divided into three subsets, three types of organs, which present distinct dynamics in their water content. The considered organs were the green and senescent leaf laminas (referred to as leaves), stems plus leaf sheathes (referred to as stems) and ears. This partition is also compatible with many radiative transfer models in which the canopy is represented as one or several layers of scatterers, representing the plant organs, and defined by their shape, orientation and dielectric properties.

Total and organ water contents were measured from emergence to physiological maturity using the same experimental protocol for sheltered and irrigated treatments. In 1994 and 1996, four samples consisting of 5 plants each were collected to evaluate the above-ground biomass (dry and fresh weights), while in 1992 samplings were realised from a $0.50 \mathrm{~m}^{2}$ quadrat without any replicate. In 1998, six samples of 6 plants each were collected to evaluate organ biomass and six others were collected from $0.23 \mathrm{~m}^{2}$ to evaluate the total biomass, leading to independent measurements for organ and total biomass. For the years 1992, 1994 and 1996, the total biomass was deduced by summing the biomass of the organs. Table I summarises the biological variables measured. The main phenological stages were noted from direct field observations.

\subsubsection{Air and canopy temperatures}

A micrometeorological station provided air temperature (2-m height) and canopy temperature (thermal infrared radiometer in nadir viewing) every hour on both covered and 
Table I. List of the biological variables included in the four datasets used in the study. $F W$ is the fresh weight of the sample (canopy or organs) and $D W$ is its dry weight (both expressed in $\mathrm{g} \cdot \mathrm{m}^{-2}$ ).

\begin{tabular}{|c|c|c|c|c|c|c|}
\hline \multirow[t]{2}{*}{ cultivar \& year } & \multirow[t]{2}{*}{ sowing date } & \multirow[t]{2}{*}{ hydric treatment } & \multicolumn{2}{|c|}{ variables measured } & \multirow{2}{*}{ sampling size } & \multirow[t]{2}{*}{ sampling frequency } \\
\hline & & & FW & DW & & \\
\hline arcour 92 & 18 Feb. 92 & irrigated \& sheltered & total & $\begin{array}{c}\text { total } \\
\text { leaves } \\
\text { stems } \\
\text { ears }\end{array}$ & $\begin{array}{c}0.50 \mathrm{~m}^{2} \\
" \\
" \\
"\end{array}$ & $\begin{array}{c}7 \text { days } \\
" \\
" \\
"\end{array}$ \\
\hline $\begin{array}{r}\text { ambral } 94 \\
96\end{array}$ & $\begin{array}{l}16 \text { Nov. } 93 \\
21 \text { Nov. } 95\end{array}$ & irrigated \& sheltered & $\begin{array}{c}\text { leaves } \\
\text { stems } \\
\text { ears }\end{array}$ & $\begin{array}{c}\text { leaves } \\
\text { stems } \\
\text { ears }\end{array}$ & $\begin{array}{c}5 \text { plants } \\
" \\
"\end{array}$ & $\begin{array}{c}7 \text { days } \\
" \\
"\end{array}$ \\
\hline armet 98 & 28 Oct. 97 & irrigated & $\begin{array}{c}\text { total } \\
\text { leaves } \\
\text { stems } \\
\text { ears }\end{array}$ & $\begin{array}{l}\text { total } \\
\text { leaves } \\
\text { stems } \\
\text { ears }\end{array}$ & $\begin{array}{c}0.23 \mathrm{~m}^{2} \\
6 \text { plants } \\
" \\
"\end{array}$ & $\begin{array}{c}7 \text { days } \\
" \\
" \\
3 \text { days }\end{array}$ \\
\hline
\end{tabular}

uncovered field sections. Several authors [10, 20, 21] have suggested replacing air temperature with either soil temperature, organ temperature or canopy temperature to describe the phasic crop development, since temperatures measured nearer the plant allow one to account, at least partly, for the effect of water stresses. Consequently, the growing degree-days (base $0{ }^{\circ} \mathrm{C}$ ) were calculated from the daily maximum and minimum of the canopy temperature, over each 24 -hour interval.

\subsection{Time scales used}

Plant age is expressed by either the number of days after sowing or a decimal phenological scale based on cumulative canopy degree-days. Four phenological stages, given in Table II, were chosen as key stages, dividing the growing season into three phases that will be referred to as juvenile, elongation and grain filling phases (though the last one begins slightly before grain filling). Within each phase, the decimal phenological scale $\theta^{*}$ is defined as the sum of degree-days accumulated since the beginning of the period:

$$
\theta^{*}=\frac{\theta-\theta_{i}}{\theta_{i+1}-\theta_{i}}+i \quad \text { with } 0 \leq i \leq 2
$$

where $\theta$ is the current cumulative degree-day (above $0{ }^{\circ} \mathrm{C}$ as base temperature), $\theta_{i}$ is the cumulative degree-day at stage $i$ (beginning of the phase) and $\theta_{i+1}$ is the cumulative degreeday at stage $i+1$ (end of the phase). Thus, the decimal phenological scale $\theta^{*}$ ranges between 0 (emergence) and 3 (physiological maturity). Table II shows that this simple decimal scale respects in proportion the intervals in-between the stages as given by the more commonly-used Zadoks' scale.

\subsection{Analysis of the water content data}

Leaves, stems, ears and total water contents were calculated using equation (2). A logistic function of time was fitted on the measured water contents for each dataset and each plant organ:

$$
W C_{0}=f(t)=\frac{a t+b}{1+\exp \left(k\left(t-t_{i}\right)\right)}
$$

where index 0 corresponds to each of the plant organs (leaves, stems and ears) and $t$ is the time scale used, either the number of days after sowing or the decimal phenological stage. The parameters $a, b, k$ and $t_{i}$ are fitted using a quasi-Newton optimiser (function nlmin from the Splus software), the cost function to be minimised being the sum of the squared differences between the observed and modelled organ water contents.

Differentiating these logistic functions allows the analytical estimation of the desiccation rate for each plant organ (expressed in $\% \mathrm{H}_{2} \mathrm{O} \cdot \mathrm{day}^{-1}$ units), as a function of time $t$ and of the current water content $W C_{O}(t)$ :

$$
\frac{d W C_{0}(t)}{d t}=f^{\prime}\left(W C_{0}, t\right)
$$

The normalisation of this desiccation rate by the water content of each organ gives the relative desiccation rate $(R D R)$ :

$$
R D R=\frac{d W C_{0}(t)}{W C_{0}} \cdot \frac{1}{d t}=\frac{f^{\prime}\left(W C_{0}, t\right)}{W C_{0}}
$$

\section{RESULTS}

\subsection{Dynamics of the water content $(W C)$ as a function of time}

For each treatment, each year and each cultivar, the total and organ water contents vary greatly with the crop age, as can be seen in Figure 1. Desiccation is very low during the vegetative phase. After earing, during the reproductive phase, the water content of organs decreases rapidly with time. When expressed in days after sowing units (see Fig. 1), the time course of water content exhibits a great variability with the sowing date, in particular between winter and spring sowing dates. This may be explained by a day-length effect on the duration of the crop growth $[6,10]$. We also observed a great

Table II. Key stages defining the phenological scale $\theta^{*}$ and corresponding decimal codes (Zadok's scale).

\begin{tabular}{lcc}
\hline phenological scale & $\begin{array}{c}\text { corresponding } \\
\text { decimal code }\end{array}$ & $\begin{array}{c}\text { equivalent } \\
\text { on Zadoks' scale }\end{array}$ \\
\hline emergence & 0 & 0 \\
beginning of stem elongation & 1 & 30 \\
earing & 2 & 60 \\
physiological maturity & 3 & 92 \\
\hline
\end{tabular}



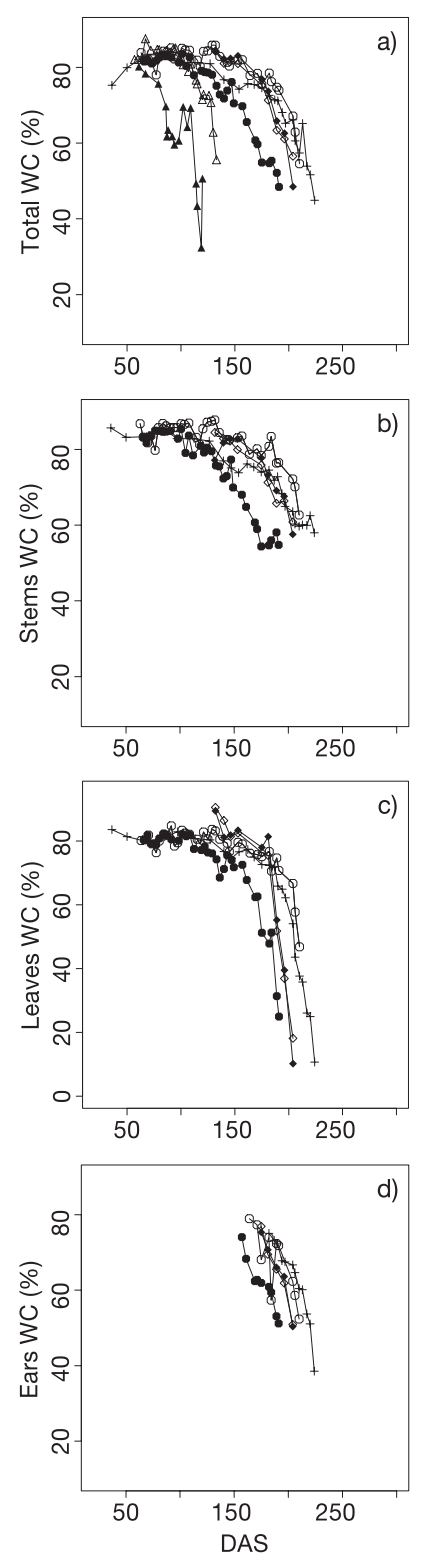

Figure 1. Time course of the water content $(W C)$ over the crop growing season, expressed in days after sowing units. (a) Total; (b) stems; (c) leaves; (d) ears.

+ indicates armet 1998, $\diamond$ ambral irrigated 1996, $\bullet$ ambral sheltered 1996, ○ ambral irrigated 1994, • ambral sheltered 1994, $\triangle$ arcour irrigated 1992, $\boldsymbol{\Delta}$ arcour sheltered 1992.

variability between treatments: when water is limited, the crop appears to accelerate its cycle the more the stress is severe [6, 28]. No or little variability of the dynamics of the water content was observed between the cultivars used in this study.

\subsection{Dynamics of water content $(W C)$ as a function of phenology}

When expressed in decimal phenological units (see Fig. 2), the effect of the duration of the growing cycle on the dynamics
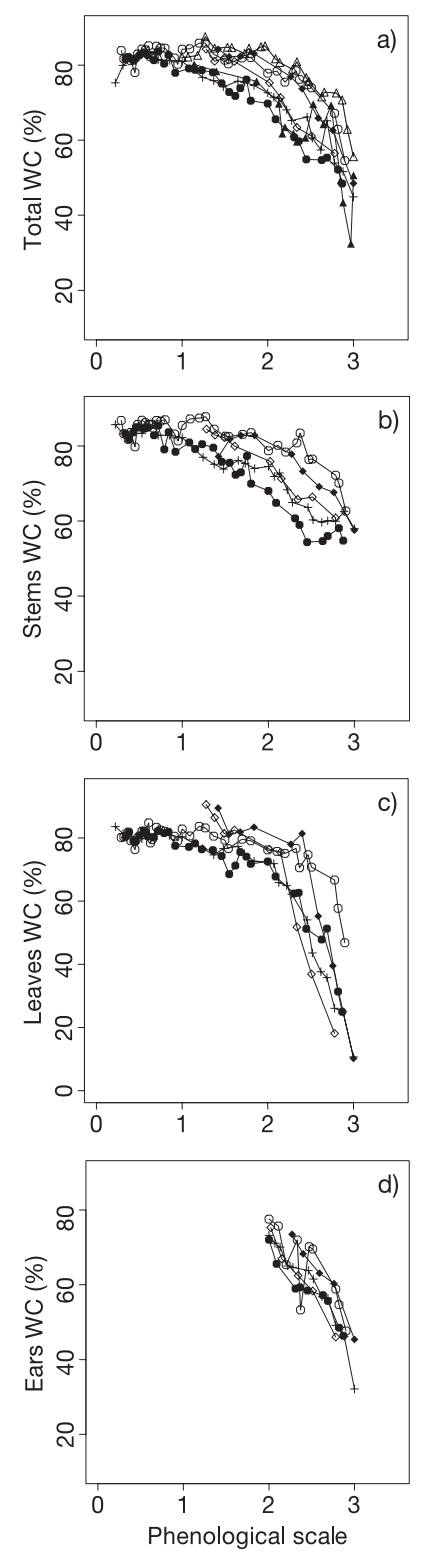

Figure 2. Time course of the water content $(W C)$ over the crop growing season, expressed in decimal phenological stage units. (a) Total; (b) stems; (c) leaves; (d) ears.

+ indicates armet 1998, $\diamond$ ambral irrigated 1996, $\bullet$ ambral sheltered 1996, ○ ambral irrigated 1994, • ambral sheltered 1994, $\triangle$ arcour irrigated 1992, $\mathbf{\Delta}$ arcour sheltered 1992.

of water content vanishes, which helps when comparing datasets. However, the effect of the treatments on the desiccation rates (slope of the curves) remains. Moreover, leaves, stems and ears clearly exhibit different desiccation rates, which justifies the analysis at the organ level rather than at the plant level. Concerning the plant phenology, one can notice that the water content is always higher at early stages than at late stages, even if water is adequately supplied. This decrease with age corresponds to an increasing concentration in the dry matter during the growing season $[13,29]$. 

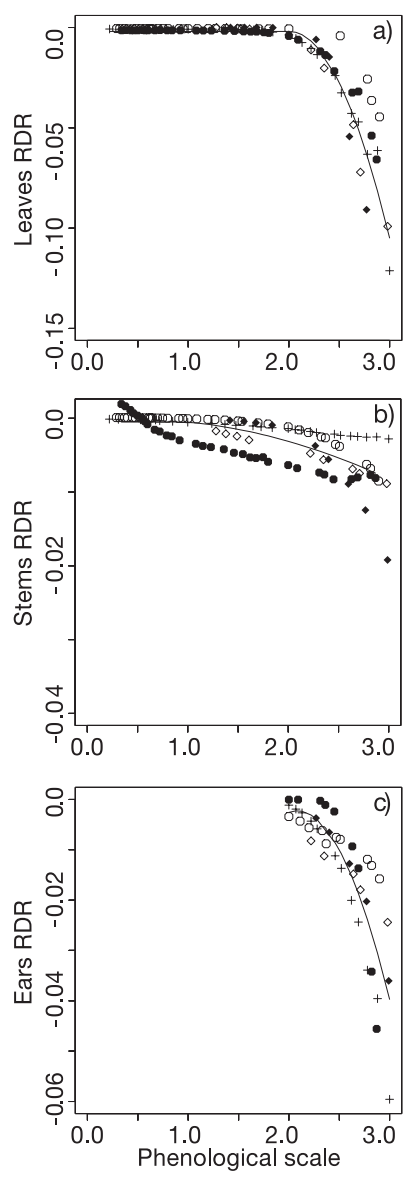

Figure 3. Time course of the relative desiccation rate $(R D R)$ over the crop growing season, expressed in decimal phenological stage units. (a) Leaves; (b) stems; (c) ears.

+ indicates armet 1998, $\diamond$ ambral irrigated 1996, $\bullet$ ambral sheltered 1996, ○ ambral irrigated 1994, • ambral sheltered 1994, $\triangle$ arcour irrigated 1992, $\boldsymbol{\Delta}$ arcour sheltered 1992.

\subsection{Dynamics of the relative desiccation rate $(R D R)$ as a function of phenology}

Figure 3 represents the $R D R$ of leaves (a), stems (b) and ears (c) calculated from equation (6). The $R D R$ of vegetative organs (leaves and stems) can be assumed to be constant (or slowly decreasing) during the juvenile phase $\left(0 \leq \theta^{*} \leq 1\right)$, taking values around $-8.1 \times 10^{-4} \mathrm{day}^{-1}$ for leaves and around $-1.8 \times 10^{-}$ ${ }^{4} \mathrm{day}^{-1}$ for stems. It then decreases steadily to around $1.2 \times 10^{-1} \mathrm{day}^{-1}$ for leaves and $-2.3 \times 10^{-3} \mathrm{day}^{-1}$ for stems at physiological maturity $\left(\theta^{*}=3\right)$. For ears, the $R D R$ decreases steadily from around $-1.1 \times 10^{-3}$ day $^{-1}$ at earing $\left(\theta^{*}=2\right)$ to around $-5.9 \times 10^{-2} \mathrm{day}^{-1}$ at physiological maturity.

Subsequently the relationship between $R D R$ and $\theta^{*}$ appeared to be the most relevant for predicting plant water content dynamics. To derive an equation relating $R D R$ and $\theta^{*}$ for each organ, we used the data of the years 1994, 1996 and 1998. For all organs and phases, the $R D R=f\left(\theta^{*}\right)$ relationship was supposed to be a polynomial function, since this type of function is known to provide good interpolations which are
Table III. Parameters of the model of organ water content (Eqs. (9) and (10)) obtained by non-linear fitting on the experimental dataset. $\mathrm{n}$ is the number of observations. The standard errors of the parameters are in italics.

\begin{tabular}{lcccccc}
\hline & $\mathrm{A}$ & $\mathrm{B}$ & $\mathrm{C}$ & $\mathrm{D}$ & $\mathrm{E}$ & $\mathrm{n}$ \\
\hline $\mathrm{WC}_{\text {leaves }}$ & 0.028 & 4.379 & -1.30 & 4.14 & -3.26 & 110 \\
& 0.060 & 0.040 & 0.24 & 0.89 & 0.79 & \\
$\mathrm{WC}_{\text {stems }}$ & -0.018 & 4.443 & -0.066 & 0.14 & -0.17 & 110 \\
& 0.042 & 0.028 & 0.038 & 0.53 & 0.48 & \\
$\mathrm{WC}_{\text {ears }}$ & & & 0.50 & -3.41 & 4.88 & 40 \\
& & & 0.22 & 0.72 & 0.44 & \\
\hline
\end{tabular}

easy to integrate. Nevertheless, the assumed degree of the polynomial function varies between organs and between phases.

For leaves and stems, we assumed that (see Fig. 3) the $R D R$ is constant during the juvenile phase $\left(0 \leq \theta^{*} \leq 1\right)$ :

$$
\frac{f^{\prime}\left(W C_{0}, \theta^{*}\right)}{W C_{0}}=\frac{d W C_{0}\left(\theta^{*}\right)}{W C_{0}} \frac{1}{d \theta^{*}}=A
$$

and that the function $R D R=f\left(\theta^{*}\right)$ is quadratic during the elongation and grain filling phases $\left(0 \leq \theta^{*} \leq 3\right)$ :

$$
\frac{f^{\prime}\left(W C_{0}, \theta^{*}\right)}{W C_{0}}=\frac{d W C_{0}\left(\theta^{*}\right)}{W C_{0}} \frac{1}{d \theta^{*}}=C \theta^{*^{2}}+D \theta^{*}+E
$$

The latter assumption is also applied to ears during the grain filling phase $\left(2 \leq \theta^{*} \leq 3\right)$, the parameters $C, D$ and $E$ taking different values.

The water content of each organ is obtained by integrating the expression of the RDR over phenological time (Eqs. (7) and (8)), leading to the following expressions:

for $0 \leq \theta^{*} \leq 1$ :

$$
W C_{0}\left(\theta^{*}\right)=\int \frac{d W C_{0}}{W C_{0}}=\exp \left(A \theta^{*}+B\right)
$$

for $1 \leq \theta^{*} \leq 3$ :

$$
W C_{0}\left(\theta^{*}\right)=\int \frac{d W C_{0}}{W C_{0}}=\exp \left(\frac{C}{3} \theta^{*^{3}}+\frac{D}{2} \theta^{2}+E \theta^{*}+F\right)
$$

The parameters of equations (9) and (10) are evaluated by nonlinear fitting on the experimental data, all the dataset being included, and the obtained values are given in Table III, the parameter $F$ being obtained by equalling equations (9) and (10) at $\theta^{*}=1$, leading to:

$$
F=A+B-C / 3-D / 2-E
$$

The water content of each organ can be calculated by substituting into equations (9) and (10) the values of the parameters given in Table III. Comparison of these calculated values with the measured ones enabled us to verify the consistency of the relationships. The results of these calculations for the entire growing season are shown in Figure 4. There was a good agreement with the measurements, for all datasets. The root mean square errors $(\mathrm{rms})$ were close to the experimental errors given in Table IV. Some slight underestimation was observed 

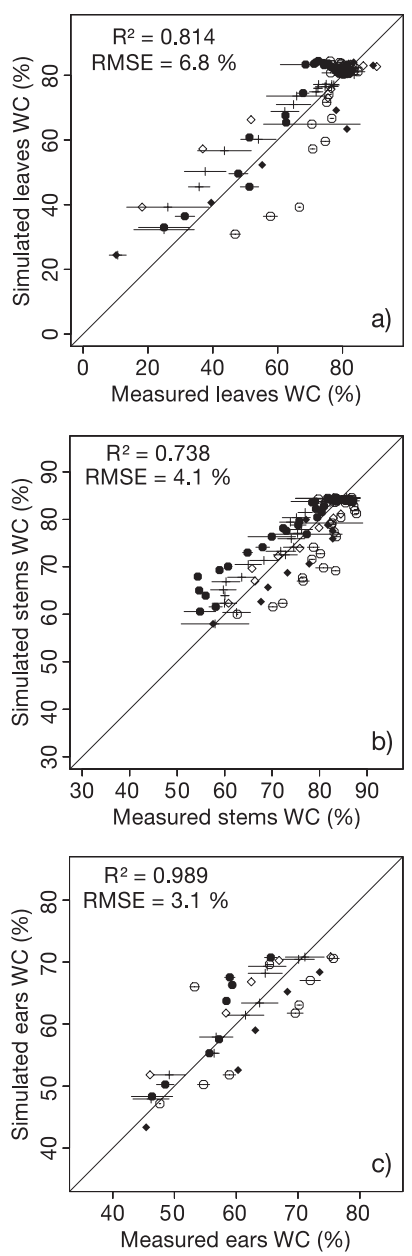

Figure 4. Comparison between measured and simulated water contents $(W C$ ) of wheat organs. (a) Leaves; (b) stems; (c) ears.

+ indicates armet 1998, $\diamond$ ambral irrigated 1996, ambral sheltered 1996, O ambral irrigated 1994, • ambral sheltered 1994, $\triangle$ arcour irrigated 1992, $\mathbf{\Delta}$ arcour sheltered 1992.

for the lower values of the leaf water content, which corresponded to the senescence phase. Correlatively, a larger scattering of the leaf water content data was also observed, but in general the contribution of the leaves to the total water content of the canopy is less significant at the end of the crop cycle.

\subsection{Testing the relationships on an independent dataset}

An independent testing of the relationships was performed on another dataset, acquired in 1996-97 during the AlpillesReSeDA experiment [22]. The experimental site was also located in the Southeast of France, $30 \mathrm{~km}$ from Avignon. The data used for this validation was acquired on two wheat fields (\#101 and \#120), sown with the cultivar armet. A very dry spring led to a pronounced water stress. A supplemental irrigation of $100 \mathrm{~mm}$ was applied to field \#120, whereas field \#101 was non-irrigated. Figure 5 presents the validation results. It shows that the relationships simulate the total and organ water contents with a reasonable accuracy. But we still
Table IV. Experimental errors (standard deviation) on the measurement of the relative water content $\mathrm{WC}_{0}$ and on the total water content of the wheat canopy (expressed in $\mathrm{kg} \cdot \mathrm{m}^{-2}$ ).

\begin{tabular}{cccccc}
\hline & $\begin{array}{c}\mathrm{WC}_{\text {leave }} \\
(\%)\end{array}$ & $\begin{array}{c}\mathrm{WC}_{\text {stem }} \\
(\%)\end{array}$ & $\begin{array}{c}\mathrm{WC}_{\text {ear }} \\
(\%)\end{array}$ & $\begin{array}{c}\mathrm{WC}_{\text {total }} \\
(\%)\end{array}$ & $\begin{array}{c}\text { total plant water } \\
\text { content }\left(\mathrm{kg} \cdot \mathrm{m}^{-2}\right)\end{array}$ \\
\hline experimental error & 7.50 & 3.74 & 13.5 & 5.43 & 0.24 \\
\hline
\end{tabular}
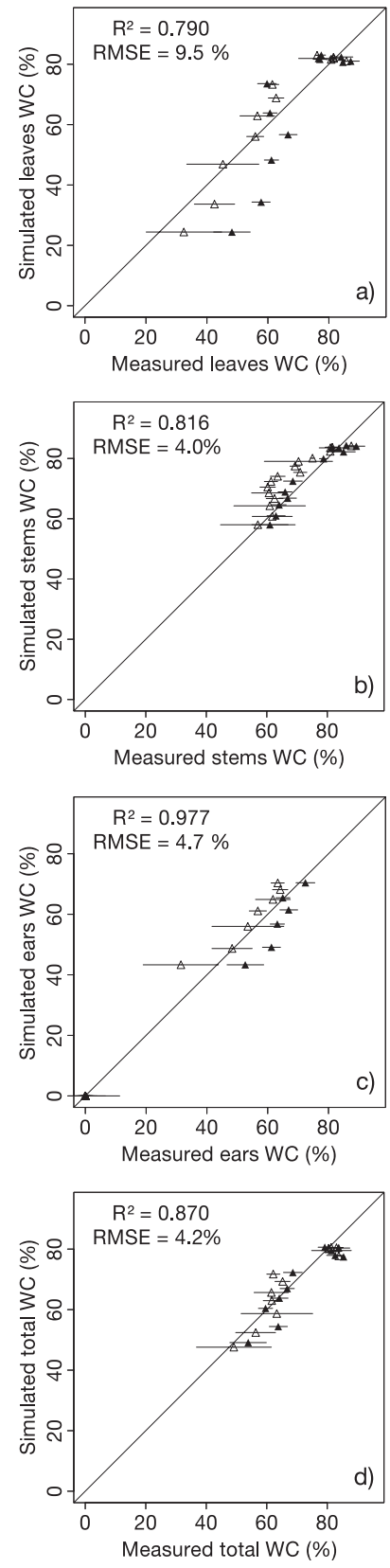

Figure 5. Validation of the model: comparison between measured and calculated water contents $(W C$ ) of the wheat organs and plant: (a) Leaves; (b) stems; (c) ears; (d) total.

$\triangle$ indicates armet field \#101, $\Delta$ armet field \#120. 


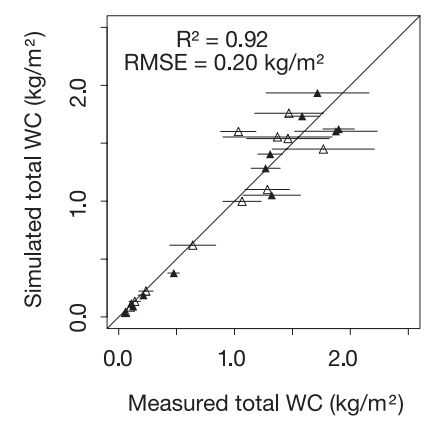

Figure 6. Comparison between measured and calculated total amount of water in the canopy.

$\triangle$ indicates armet field \#101, $\boldsymbol{\Delta}$ armet field \#120.

observed a slight underestimation of the water content of the leaves, for the lower values of their water content.

The total plant water content $\left(\mathrm{kg} \mathrm{H}_{2} \mathrm{O} \cdot \mathrm{m}^{-2}\right)$ was also calculated for these fields by applying the water content relationships (Fig. 6): the predicted plant water content was in good agreement with the measured one and the error of prediction $\left(r m s=0.20 \mathrm{~kg} \cdot \mathrm{m}^{-2}\right)$ was close to the measurement uncertainties $\left(0.24 \mathrm{~kg} \cdot \mathrm{m}^{-2}\right.$, see Tab. IV).

\section{DISCUSSION AND CONCLUSION}

Our results confirm some of the various sources of variability of the canopy water content: (i) between organs, (ii) as a function of plant age, and (iii) between water treatments.

The organ source of variability led us to work at the organ (leaves, stems and ears) level rather than at the plant level [17, 29]. This allowed a better analysis of the evolution of the canopy water content, since the various organs exhibit distinct dynamics in the evolution of their water content, that can be masked when investigating at the plant level.

Replacing the timescale with a phenological scale removed the effect of the growing season duration, thus permitting a comparison of the various treatments. In fact, the principle of decimal scales for quantifying phenology has long been used for cereals $[31,34]$. The advantage of the four key phases chosen (see Tab. II) is that they correspond to canopy structure modifications that are easily observed in the field and that are also related to modifications of the remote sensing signals. Canopy temperatures were preferred to air temperature since they allowed accounting for the effect of the water stress, at least partly $[10,20,21]$.

We have built up a set of relationships describing the dynamics of the relative water content of organs as a function of phasic development. Those relationships were tested on data independent from those used to build them. Subsequently they constitute a regional model valid for durum wheat grown in similar conditions. One of the main lessons of this model is that phenology seems to explain a great part of the variability in the water content of plant organs. However, all factors affecting leaf senescence are likely to affect the parameters of the relationships: e.g. water stress, nitrogen deficiency [14] and diseases. Part of the effect of water stress is accounted for by the use of the canopy temperature as a driving variable of the phenological scale. But accounting for the stress through the canopy temperature is not sufficient to explain the variability observed between trials in the evolution of $W C$, especially for stems (see Fig. 2).

Another use of our result can be made by inverting the model to derive the main phenological stages, with an a priori knowledge of the growing degree-days. For example, Huet [15] demonstrated a good stability of the relationship between the water content of stems $\left(W C_{\text {stem }}\right)$ and the earing stage. Bauer et al. [5] have shown that the relative water content of ears $\left(W C_{e a r}\right)$ is a good indicator of the physiological maturity of wheat. Moreover, $W C_{e a r}$ is connected with the beginning $\left(W C_{\text {ear }}=65 \%\right)$ and the end $\left(W C_{\text {ear }}=40 \%\right)$ of the linear growth phase of the grain [7]. It is thus possible to predict the optimum wheat harvesting dates from $W C_{\text {ear }}$ measurements.

The integration of this model of wheat organ water content into any crop simulation model (STICS [8], SWHEAT [31], ARCWHEAT [32], CERES-Wheat [25], etc.) is possible, provided the crop model includes a partitioning of the dry biomass between organs (leaves, stems and ears). The accuracy of the predicted water content of organs will primarily depend on the quality of the prediction of the phenological stages by the crop model.

The main application of this description of the dynamics of wheat water content concerns the interpretation and use of microwave remotely-sensed data. As the water content of plants strongly affects their dielectric properties, our model allows the coupling of crop models with various radiative transfer codes, either semi-empirical models [1] or more sophisticated ones, thanks to the partitioning between organs. This coupling should permit the simulation of the microwave response of wheat canopies, throughout the crop cycle. An important application of such a coupling is to account for the effect of the canopy when estimating the surface soil moisture of vegetation-covered soils from radar data [24]. Our description of the dynamics of the wheat water content can also be applied to the solar part of the spectrum (from the visible to the short-wave middle infrared), since the water content of the plant organs has a large influence on their optical properties.

The modelling of the dynamics of wheat water content presented in this paper has already been used in coupling the STICS crop model with radiative transfer codes in the solar and radar spectral domains, allowing adequate simulations of the radiometric signatures of wheat canopies, throughout the crop cycle [33]. This coupling of a crop model with radiative transfer codes can ultimately be employed for re-calibrating or forcing the crop model, using remote sensing observations, thus allowing one to account for the actual growth conditions [23].

\section{REFERENCES}

[1] Attema E.P.W., Ulaby F.T., Vegetation modeled as a water cloud, Radio Sci. 13 (1978) 357-364.

[2] Baret F., Guyot G., Bégué A., Maurel P., Podaire A., Complementarity of middle-infrared with visible and near-infrared 
reflectance for monitoring wheat canopies, Remote Sens. Environ. 26 (1988) 213-225.

[3] Barlow E.W.R., Lee J.W., Munns R., Smart M.G., Water relations of the developing wheat grain, Aust. J. Plant Physiol. 7 (1980) 519-525.

[4] Barrs H.D., Determination of water deficits in plant tissues, in: Kozlowski T.T. (Ed.), Water deficits and plant growth, Vol. 1, 1968, pp. 235-368.

[5] Bauer A., Frank A.B., Black A.L., Estimation of spring wheat spike water concentration and grain maturity from air temperature, Agron. J. 78 (1986) 445-450.

[6] Blum A., Crop responses to drought and the interpretation of adaptation, Plant Growth Regul. 20 (1996) 135-148.

[7] Boissard P., Pointel J.G., Huet P., Reflectance, green leaf area index and ear hydric status of wheat from anthesis until maturity, Int. J. Remote Sens. 14 (1993) 2713-2729.

[8] Brisson N., Mary B., Ripoche D., Jeuffroy M.H., Ruget F., Nicoullaud B., Gate P., Devienne-Barret F., Antonioletti R., Durr C., Richard G., Beaudoin N., Recous S., Tayot X., Plenet D., Cellier P., Machet J.M., Meynard J.M., Delécolle R., STICS: a generic model for the simulation of crops and their water and nitrogen balances. I. Theory and parameterization applied to wheat and corn, Agronomie 18 (1998) 311-346.

[9] Brooks A., Jenner C.F., Aspinal D., Effects of water deficit on endosperm starch granules and on grain physiology of wheat and barley, Aust. J. Plant Physiol. 9 (1982) 423-436.

[10] Casals M.L., Introduction des mécanismes de résistance à la sécheresse du blé dur au fonctionnement phénologique et trophique de la plante dans un modèle dynamique de croissance, Thesis INA-PG, Paris (France), 1996, p. 130.

[11] Cruiziat P., L'état hydrique des plantes : rappel et utilisation, in Fonctionnement hydrique des plantes : relations avec la physiologie, D. d. B. INRA, Daudet, F.A., Ed., 1992, pp. 1-16.

[12] Curtis O.F., Clark D.G., An introduction to plant physiology, McGraw-Hill Book Company, 1950.

[13] Gate P., Écophysiologie du blé : de la plante à la culture, ITCF \& Lavoisier (Eds.), 1996.

[14] Girard M.L., Modélisation de l'accumulation de biomasse et d'azote dans les grains de blé tendre d'hiver (Triticum aestivum L.) : simulation de leur teneur en protéines à la récolte, Thesis INA-PG, 96 p., 1997.

[15] Huet M., Évolution des paramètres de structure et de biomasse d'un couvert de blé. Utilisation des techniques de télédétection micro-ondes, Thesis Université Paul Sabatier, Toulouse (FRA), 1983, p. 110 .

[16] Jackson T.J., Schmugge T.J., Vegetation effects on the microwave emission of soils, Remote Sens. Environ. 36 (1991) 203-212.

[17] Katerji N., Les grandeurs de référence utilisables pour caractériser l'état hydrique chez les plantes cultivées, in: International conference on supplementary irrigation and drought water management, Vol. 3, 1992.

[18] Kramer P.J., Plant relative water content and related methods: historical perspectives and current concerns, in: International conference on measurement of soil and plant water status, Vol. 2Plants, 1987, pp. 1-8.
[19] Livingston B.E., Brown W.H., Relation of the daily march of transpiration to variations in the water content of foliage leaves, Bot. Gaz. 53 (1912) 309-330.

[20] Ong C.K., Response to temperature in a stand of pearl millet (Pennisetum typhoides S and H). I: Vegetative development, J. Exp. Bot. 34 (1983) 332-336.

[21] Parajasingham S., Hunt L.A., Wheat Spike Temperature in Relation to Base Temperature for Grain Filling Duration, Can. J. Plant Sci. 71 (1991) 63-69.

[22] Prévot L., Chauki H., Rémond A., King C., Wigneron J.P., Chanzy A., Calcagno P., Desprats J.F., Comparison of ERS and multiangular RadarSat measurements over agricultural canopies: first results of the Alpilles-ReSeDA campaign, presented at 2nd International Workshop on Retrieval of Bio- and Geo-physical Parameters from SAR Data for Land Applications, Noordwijk (NL), 1998.

[23] Prévot L., Chauki H., Troufleau D., Weiss M., Baret F., Brisson N., Assimilating optical and radar data into the STICS crop model for wheat, presented at 8th International Symposium Physical Measurements \& Signatures in Remote Sensing, Aussois, France, 2001, CNES-ISPRS (Eds.), pp. 753-758.

[24] Quesney A., Le Hégarat-Mascle S., Taconet O., Vidal-Madjar D., Wigneron J.P., Loumagne C., Normand M., Estimation of watershed soil moisture index from ERS/SAR data, Remote Sens. Environ. 72 (2000) 290-303.

[25] Ritchie J.T., Otter S., Description and performance of CERESWheat, a user-oriented wheat yield model, USDA-ARS-SR Grassland Soil and Water Research, Temple RX., (1984), pp. 159175.

[26] Slatyer R.O., Plant-water relationships, Academic Press, London, 1967.

[27] Tucker C.J., Remote sensing of leaf water content in the near infrared, Remote Sens. Environ. 10 (1980) 23-32.

[28] Turner N.C., Grain production and water use of wheat as affected by plant density, defoliation and water status, Thesis University of Adelaide, South Australia, 1966.

[29] Turner N.C., Techniques and experimental approach for the measurements of plant water status, Plant and Soil (1981) 339336.

[30] Ulaby F.T., Moore R.K., Fung A.K., Microwave remote sensing Active and passive. Volume III, From theory to applications, Artech house, 1986.

[31] van Keulen H., Seligman N.G., Simulation of water, use nitrogen nutrition and growth of spring wheat crop, Simulation monograph PUDOC, Wageningen, The Netherlands, 1987.

[32] Weir J.R., Bragg P.L., Porter J.R., Rayner J.H., A winter wheat crop simulation model without water or nutrient limitations, J. Agric. Sci. 102 (Camb.) (1984) 371-382.

[33] Weiss M., Troufleau D., Baret F., Chauki H., Prévot L., Olioso A., Bruguier N., Brisson N., Coupling canopy functioning and canopy radiative transfer models for remote sensing data assimilation. The case of winter wheat, Agric. Forest Meteorol. 108 (2001) 113-128.

[34] Zadoks J.C., Chang T.T., Knozak C.F., A decimal code for the growth stages of cereals, Weed Res. 14 (1974) 415-421. 